\title{
MÉSZÁROS BENCE
}

\section{A kriminálstratégia önállósodása}

A kriminalisztika és a kriminológia határán elhelyezkedő, hazánkban ma még viták tárgyául szolgáló diszciplínának, a kriminálstratégiának a magyar rendészeti felsőoktatásban tapasztalható önállósodását mutatom be, bepillantást engedve ezáltal a Nemzeti Közszolgálati Egyetem Rendészettudományi Kar életének igen mozgalmas és egyben nagyon konstruktív időszakába, a 2015 és 2018 között eltelt évekbe ${ }^{1}$. Fontos hangsúlyozni azonban, hogy a cím a cikkben ismertetett fejlemények ellenére jelenleg még inkább a Sollent, mintsem a Seint fejezi ki.

\section{A bünügyi stratégiai tanszék megalapítása}

A Nemzeti Közszolgálati Egyetem fenntartói testülete 24/2014. (V. 29.) számú határozatában egyetértett azzal, hogy az egyetem megalapítsa a bünügyi stratégiai tanszéket, abból a célból, hogy a későbbiekben létrejövő kriminalisztikai intézet egyik tanszéke legyen.

Az intézet és ezzel együtt a tanszék végül 2015. szeptember 1-jén alakult meg. A tanszéket elsősorban a kriminálstratégia, valamint a kriminalisztika elméletével kapcsolatos más tantárgyak oktatására hozták létre, de az új szervezeti egység vonatkozásában megfogalmazott kívánalom volt az is, hogy tagjai kísérjék figyelemmel a külföldön a bünüldözésben alkalmazott megoldásokat, modelleket, és közvetítsék azokat a hallgatóknak, illetve a hazai szakmai közvéleménynek. Fontos szempont volt a tanszék megalakításánál, hogy a személyi állománya tevékenyen részt vegyen a rendészettudományi kar által indítandó kriminalisztika mesterképzési szak létrehozásában, illetve az azon folyó oktatásban.

\footnotetext{
1 Ebben az időszakban jött létre a Kriminalisztikai Intézet, a Rendészeti Magatartástudományi Intézet, a Közjogi és Rendészettani Intézet, a kiberbünözés elleni tanszék, alakult meg a Rendészettudományi Doktori Iskola. E periódusban rendezte meg a rendészettudományi kar a XXXIII. OTDK had- és rendészettudományi szekciójának versenyét, dolgozta ki és indította el a bűnügyi és a rendészeti alapszak négyéves tantervét és képzését, és költözött a Farkasvölgyi úti campusról a Ludovika egyetemi campusra, hogy csak néhány nagy volumenű eseményt említsek a teljesség igénye nélkül.
} 
Az új szervezeti egység három fôvel kezdte meg munkáját (ez 2017-ben négyre bővült), és azonnal bekapcsolódtak a kriminalisztika mesterképzési szak kidolgozásának munkálataiba, továbbá jelentős szerepük volt e munka sikerében ${ }^{2}$, abban, hogy 2017 szeptemberében megkezdhette tanulmányait az első évfolyam a mesterszak rendészeti és polgári szakirányán is.

A mesterképzési szak célját a 282/2016. (IX. 21.) kormányrendelet a következőképpen fogalmazza meg: „, A képzés célja olyan rendészeti szakemberek képzése, akik a tanulmányaik során elsajátitott szakmai ismereteik birtokában magas szinten képesek közremüködni a bünügyi felderitö és nyomozati munkában, továbbá alkalmazva a legkorszerübb vizsgálati módszereket és taktikai ajánlásokat elö tudják segiteni, illetve közre tudnak müködni a hatékony, megalapozott, tudományos és törvényes bizonyitás lefolytatásában. Cél továbbá olyan magas elméleti tudással rendelkezö szakemberek kibocsátása, akik rendelkeznek olyan szakmai szintetizáló képességgel, bizonyitáselméleti tudással, ami képessé teszi öket a jövő bünügyi tendenciáinak felismerésére és operativ stratégiák kidolgozására. [...] A szakon végzettek az elsajátitott magas szintü és széles spektrumú ismeretek birtokában alkalmassá válnak bünügyi vezetői feladatok hatékony megoldására is, továbbá tanulmányaik doktori képzésben történö folytatására.”

Mint látható, az „okleveles kriminalista rendészeti szakirányon”, illetve „okleveles kriminalista polgári szakirányon” végzettséget adó képzés egyik célja a stratégiai szemlélettel bíró bünügyi szakemberek oktatása, a kriminálstratégia és rokon tantárgyainak tanítása tehát nélkülözhetetlen a képzésben.

\section{A kriminálstratégia fogalma és helye a bünügyi tudományok rendszerében}

A kriminálstratégiát a német (és az osztrák) tudományban a kriminalisztika harmadik ágának tekintik a krimináltechnika és a krimináltaktika mellett. Fogalmát a következők szerint határozzák meg: „A kriminálstratégia a kriminalisztika azon része, amely a bünözés helyzetére vonatkozó objektív adatokra és a lakosság szubjektív biztonságérzetére alapozva a bünözés elleni küzdelmet szolgáló intézkedések összességének tervezésével és szervezésével

2 A kriminalisztika mesterszak indítását a Magyar Akkreditációs Bizottság a 2016/6/XIII/3. számú határozatában támogatta. 
foglalkozik. Ennek során figyelembe veszi a szervezeti célt meghatározó jogi, gazdasági, kulturális, történelmi, politikai és szociális keretfeltételeket."

A német szakirodalomban a XX. század hetvenes éveiben születtek az első meghatározások. A Németországban klasszikus kriminalisztikai münek számító, 1978-as Handbuch der Kriminalsitik még csak egy visszafogott utalást tartalmazott arra, hogy a kriminálstratégia fogalma legalábbis viták tárgya: „, A kriminalisztika keretein belül néhányan »kriminálstratégia « fogalma alatt egy olyan speciális területet értenek, amely a taktikai és operativv intézkedések magas, illetöleg legmagasabb kriminalisztikai szinten való koordinálásról szól. Másként megfogalmazva, valamennyi erö együtthatásának müvészetéröl beszélünk a kriminálpolitikai célok elérésénél."

1986-ban megjelenő müvében a Manfred Klink - Siegfried Kordus szerzőpáros a következő meghatározást adta: „A krimináltaktikával ellentétben a kriminálstratégia nem az egyes büncselekmények leküzdéséhez szükséges kriminalisztikai szabályokat célozza, hanem a bünözéssel mint összjelenséggel szembeni fellépést, amelynél lehetöség van szükitésre büncselekménytípus, regionális és szakspecifikus vonatkozások szerint. A kriminálstratégia mint tudományterület a preventiv és repressziv bünözés elleni küzdelem politikailag és jogilag meghatározott megbizatása megvalósitásának tana is, átfogóan tervezett, belső és külsö szereplök által koordinált közép- és hosszútávon megvalósitandó intézkedések révén, amelyek végrehajtásakor a hatékonysági szempontot is figyelembe kell venni." (Ök a kriminalisztikát - így a kriminálstratégiát is - még a kriminológia részének tekintették).

A Németországban leginkább elfogadott, a már idézett definíció a kilencvenes évek közepére kristályosodott ki a korábban létező meghatározások továbbfejlesztésének következtében. Annak ellenére, hogy a kriminalisztikával foglalkozó hazai szerzők már a 2000-es évek első felében értekeztek arról, hogy a kriminálstratégia a kriminalisztika része ${ }^{6}$, hazánkban inkább a kriminológia részének tekintik, és többnyire azonosítják a kriminálpolitikával. A német és a magyar felfogás közötti alapvető különbség, hogy az előbbi megközelítés szerint a kriminálpolitika megvalósításához kriminálstratégiákat kell kidolgozni. Maga a „kriminálstratégia” elnevezés is viták tárgya, Finszter Gé-

3 Ralph Berthel - Mathias Lapp: Kriminalstrategie. C. F. Müller GmbH, Heidelberg, 2017, S. 27.

4 Hans Gross - Friedrich Geerds: Handbuch der Kriminalistik. Band 2. J. Schweitzer, Berlin, 1978. Idézi Ralph Berthel: Kriminalstrategie gestern und heute. Teil 1. Kriminalistik, Nr. 11, 2005, S. 619.

5 Manfred Klink - Siegfried Kordus: Kriminalstrategie. Grundlagen polizeilicher Verbrechensbekämpfung. Richard Boorberg Verlag, Stuttgart-München-Hannover, 1986, S. 23-24.

6 Lásd Mészáros Bence: A kriminálstratégia szerepe a bünözés elleni küzdelemben. Belügyi Szemle, 2016/11., 72-80. o. 
$z a$ szerint helyesebb bünüldözési stratégiának nevezni: , $A$ bünüldözési stratégia (az idegen nyelvü szakirodalomban kriminálstratégia) magában foglalja a bünüldözés célkitüzéseit, valamint - e célok megvalósitása érdekében - a büncselekmények elleni küzdelem legeredményesebb eszközeinek és módszereinek a távlati fejlesztését."

A kifejezés egyébként a német Kriminalstrategie szó tükörfordítása. Megjegyzendő, hogy Németországban a rendőrképzés csúcsának számító intézményben, a münsteri Német Rendőrföiskolán (Deutsche Hochschule der Polizei) a Bünügyi és Jogtudományok nevü intézet öt szakterületéből kettő foglalkozik a kriminálstratégiával (a Kriminalisztika - a kriminálstratégia alapjai, illetve a Kriminalisztika - jelenségorientált kriminálstratégia nevü szakterületek). E két szakterület a Német Rendőrföiskola Közigazgatás rendőri vezetés címü, kétéves mesterképzési moduljai közül háromnak az oktatásában vesz részt.

\section{A kriminálstratégia és rokon tantárgyai a kriminalisztika mester- és a doktori képzésben}

A kriminálstratégia mint tantárgy az említett tudományos fejlődésre, a német partnerintézmény mintájára és a mesterképzési szak képzési és kimeneti követelményeinek korábban ismertetett elvárásaira tekintettel bekerült a kriminalisztika mesterképzési szak szakmai törzsanyagába (a második szemeszter órarendjébe, beszámolóhoz kötött előadásként, tizenkét órában). A tantárgy leírása szerint ,, a hallgató megismerkedik a kriminalisztika negyedik pillérét képezö kriminálstratégia fogalmával, a stratégiai tervezés kriminalisztikai-, szervezéstani-és logisztikai szintjeivel, a bünüldözés kriminálprognosztikára alapitott távlatos célkitüzéseivel és a célok megvalósitásához szükséges szervezeti, anyagi- pénzügyi és módszertani feltételekkel. A tananyag elsajátítása alapot nyújt ahhoz, hogy szakmai gyakorlat birtokában a kriminalisztika MA diploma birtokosai megismerjék a rendészeti szervek müködésének jogi és elméleti alapjait, valamint maguk is részt vállalhassanak a kriminálstratégiai tervezésben, illetve az ilyen tervek megvalósitásában."

Nem szabad megfeledkezni azonban a kriminálstratégia rokon tantárgyairól sem, amelyek szintén helyet kaptak a mesterképzési szak tantervében: a kriminalisztikaelmélet, a bűnelemzés, a prediktív rendészet, a rendészeti ér-

7 Finszter Géza: Rendészettan. Dialóg Campus Kiadó, Budapest, 2018, 353. o. 
tékelö-elemző munka, a rendészeti logisztika, valamint a bünüldözés földrajza mint szabadon választható tantárgy. Közülük is a prediktív rendészetet emelem ki, mivel meglátásom szerint jelenleg külföldön a bünüldözés egyik legígéretesebb irányvonalát jelenti. A tantárgyleírás szerint „, a rendészeti kutatások és arra épülö gyakorlat a bünözés mennyiségi és minöségi változásai, továbbá a bünözés egyes megnyilvánulásainak transznacionális jellege miatt egyre nagyobb hangsúlyt fektet a bünügyi kockázatok, fenyegetések elözetes detektálására, felmérésére alapuló elöjelzö és figyelmeztetö módszerek és rendszerek alkalmazására. A kurzus során a hallgatók azokkal a nemzetközi - föleg az EU - gyakorlatában alkalmazott megoldásokkal ismerkednek meg, melyek hazai bünügyi hasznositása kedvezö hatást gyakorolhat a bünmegelözésre és a bünüldözésre."

A prediktív rendészet lényege, hogy a bünüldözés korlátozott erőforrásait bünügyi elemzések alapján azokra a helyekre és időpontokra koncentrálja, ahol az alkalmazott előrejelzési modell (egy számítógépes program futtatása) alapján nagy valószínüséggel büncselekmény fog történni.

2015-ben megalakult a Nemzeti Közszolgálati Egyetem Rendészettudományi Doktori Iskolája, amely három kutatási területen nyújt lehetőséget a rendészettudomány mélyebb müvelésére:

1. Általános rendészetelmélet, rendészettörténet, nemzetbiztonság és rendészet.

2. Szakrendészetek, a rendészet európai uniós és nemzetközi vonatkozásai.

3. A rendészet jogi, kriminológiai, kriminalisztikai és társadalomtudományi aspektusai.

A doktori iskola létrejötte és a képzés 2016-ban történő kezdete nagy lépés volt a rendészettudomány hazai életében, hiszen egészen addig a rendészeti tárgyú kutatási témákat csak a jogi egyetemek doktori iskolái, esetleg a hadtudományi doktori iskolák tudták befogadni, most már van lehetőség kifejezetten a rendészettudomány területén is $\mathrm{PhD}$-fokozatot szerezni.

A doktori képzésben is megjelent a kriminálstratégiai megközelítés: a 2018-2019-es tanév témakiírásába bekerült $A$ kriminálstratégia szerepe a bünözés elleni küzdelemben címü kutatási téma. Az előbbiekben leírt kutatási területek közül a harmadiknak a keretében helyet kapó témakiíráshoz tartozó kutatások fó célja a kriminálstratégia külföldi mintáinak feltárása, azok hazai adaptálási módjainak kidolgozása, a stratégiai tervezés elemeinek azonosítása a hazai bünözés elleni küzdelemben, azok továbbfejlesztési módjainak kimunkálása. 2018 öszén két hallgató is megkezdte tanulmányait a Rendészettudományi Doktori Iskolában az e körbe tartozó kutatási témájával. 
Szintén megemlítendő a kriminálföldrajz nevü doktori tantárgy, amelynek keretén belül a hallgatók megismerkedhetnek egy új, eddig más hazai felsöoktatási intézményben nem tanított diszciplínával. Az oktatók bemutatják a tudományág legfontosabb fogalmait, szakkifejezéseit, célkitüzéseit, hazai és nemzetközi képviselőit, az előadásokon kriminálföldrajzi aspektusból elemzik Magyarország, illetve kilenc hazai nagyváros bünügyi helyzetét. Az órán a hallgató betekinthet a bünözési térképezésbe, amelynek során a „forró pontokkal", a bünözési térképek fajtáival, azok elemzési módszereivel és készítésükkel ismerkedhet meg.

\section{Összegzés}

A kriminálstratégia fogalma, mibenléte, funkciói, a kriminálpolitikához való viszonya, helye a bünügyi tudományok rendszerében hazánkban még viták tárgya, nem általánosan elfogadott tétel, hogy a kriminalisztika egyik külön ágát jelenti. Mindamellett meggyőződésem, hogy a bünüldöző szervek vezetőinek a stratégiai szemléletet alkalmazva kell munkájukat ellátniuk annak érdekében, hogy minél hatékonyabban tudják felhasználni a rendelkezésükre álló erőforrásokat. A Nemzeti Közszolgálati Egyetem Rendészettudományi Karán ezért kollégáimmal arra törekszünk, hogy hallgatóinkkal megismertessük és számukra átadjuk azokat az ismereteket, amelyek birtokában képesek lesznek közép- és hosszú távú stratégiák alkalmazására a bünüldözésben, és azok eredményeinek megfelelő értékelésére. 